\title{
Comparative Study of NPC and Cascaded Converters Topologies
}

\author{
Mamadou Baldé $^{\mathbf{1}}$, Mamadou Lamine Doumbia ${ }^{\mathbf{1}}$, Ahmed Chériti ${ }^{1}$, Chellali Benachaiba ${ }^{2}$ \\ ${ }^{1}$ Department of Electrical and Computer Engineering \\ Université du Québec à Trois-Rivières \\ Trois-Rivières, Canada \\ ${ }^{2}$ Department of Technologies \\ University Center of Bechar \\ Bechar, Algeria
}

\begin{abstract}
Multilevel converters have many advantages which are the capacity to generate a very good quality of waveforms, the reduced switching frequency, the low energy loss and the low effort on power devices. They are used in different power electronic applications including statics synchronous compensators (STATCOM). This paper presents a comparative study of Neutral Point Clamped (NPC) and H-bridge cascaded converters. A theoretical analysis of NPC and cascaded multilevel is presented. The generalized study for $\mathrm{N}$ levels converters topologies is derived. The theoretical study is validated using computer simulation in Matlab/Simulink/SimpowerSystems environment. Output voltage and total harmonic distortion are compared.
\end{abstract}

Key words- Multilevel converters, NPC converter, H cascaded converter, static synchronous compensator

\section{Introduction}

The interest for multilevel converters comes from their capacity to provide higher power, to generate good quality of waveforms, to operate at low switching frequency with low loss of energy and the low effort on statics devices [1], [2]. Among multilevel converters topologies, there are the Neutral Point Clamped (NPC) converter, the cascaded H-bridge multilevel converter and the imbricated cell multilevel converter [1], [3].

For the NPC converters, the number of levels can be defined as:

$$
N=\frac{m}{2}+1
$$

where $m$ is the number of switches per phase.

For the cascaded H-brigde multilevel converters, the number of levels is determinate by:

$$
N=2 N H+1
$$

where $\mathrm{NH}$ is the number of bridges per phase.
In a general, the number of levels is determinate by:

$$
N=P+1
$$

where $\mathrm{P}$ is the number of complementary pairs of switches per phase.

The NPC converter and cascaded H-bridge multilevel converter are most widespread topologies in STATCOM applications. This paper presents a comparative study of Neutral Point Clamped (NPC) and H-bridge cascaded converters. A theoretical analysis of NPC and cascaded multilevel is presented. The generalized study for $\mathrm{N}$ levels converters topologies is derived. Output voltage and total harmonic distortion are compared.

\section{Theoretical Analysis}

\section{A. NPC Converter}

Three phase NPC converter with five levels of voltage is shown on Figure 1. Each phase is made of eight controlled switches which are unidirectional in voltage and bidirectional in current and six maintaining diodes connected along the continued bus. The converter is powered by a DC source V, connected to four capacitors of equal values.

Our study is limited to a leg of NPC converter with five levels. The voltage values $\mathrm{v}_{\mathrm{a}}$ are determined for different operating conditions and the switching sequences of the statics devices are presented. Five switching sequences can be identified:

- Sequence 1 (Figure 2-a) :

$\mathrm{K}_{1}, \mathrm{~K}_{2}, \mathrm{~K}_{3}$ and $\mathrm{K}_{4}$ are on and $\mathrm{K}_{5}, \mathrm{~K}_{6}, \mathrm{~K}_{7}$ and $\mathrm{K}_{8}$ are off. The point a is connected to the positive terminal of the first voltage level $\frac{\mathrm{V}}{4}$ and the point $\mathrm{O}$ is connected to the negative terminal 
of the second voltage level $\frac{\mathrm{V}}{4}$, that the output voltage value is: $\mathrm{V}_{\mathrm{ao}}=+\frac{\mathrm{V}}{2}$.

- Sequence 2

$\mathrm{K}_{2}, \mathrm{~K}_{3}, \mathrm{~K}_{4}$ and $\mathrm{K}_{5}$ are on and $\mathrm{K}_{6}, \mathrm{~K}_{7}, \mathrm{~K}_{8}$ and $\mathrm{K}_{1}$ are off, the output voltage value is: $\mathrm{V}_{\mathrm{ao}}=+\frac{\mathrm{V}}{4}$

- $\quad$ Sequence 3 (Figure 2-b)

$\mathrm{K}_{3}, \mathrm{~K}_{4}, \mathrm{~K}_{5}$ and $\mathrm{K}_{6}$ are on and $\mathrm{K}_{7}, \mathrm{~K}_{8}, \mathrm{~K}_{1}$ and $\mathrm{K}_{2}$, are off, the output voltage is: $\mathrm{V}_{\mathrm{ao}}=0$

- Sequence 4: (Figure 2-c)

$\mathrm{K}_{4}, \mathrm{~K}_{5}, \mathrm{~K}_{6}$ and $\mathrm{K}_{7}$ are on and $\mathrm{K}_{8}, \mathrm{~K}_{1}, \mathrm{~K}_{2}$ and $\mathrm{K}_{3}$ are off, the output voltage is: $\mathrm{V}_{\mathrm{ao}}=-\frac{\mathrm{V}}{4}$

- Sequence 5

$\mathrm{K}_{5}, \mathrm{~K}_{6}, \mathrm{~K}_{7}$ and $\mathrm{K}_{8}$ are on-by and $\mathrm{K}_{1}, \mathrm{~K}_{2}, \mathrm{~K}_{3}$ and $\mathrm{K}_{4}$, are blocked, the off voltage is: $\mathrm{V}_{\mathrm{ao}}=-\frac{\mathrm{V}}{2}$

The reverse voltage of power switches is: $\mathrm{V}_{\mathrm{ki}}=+\frac{\mathrm{V}}{4} \mathrm{i}=1 \ldots . .8$

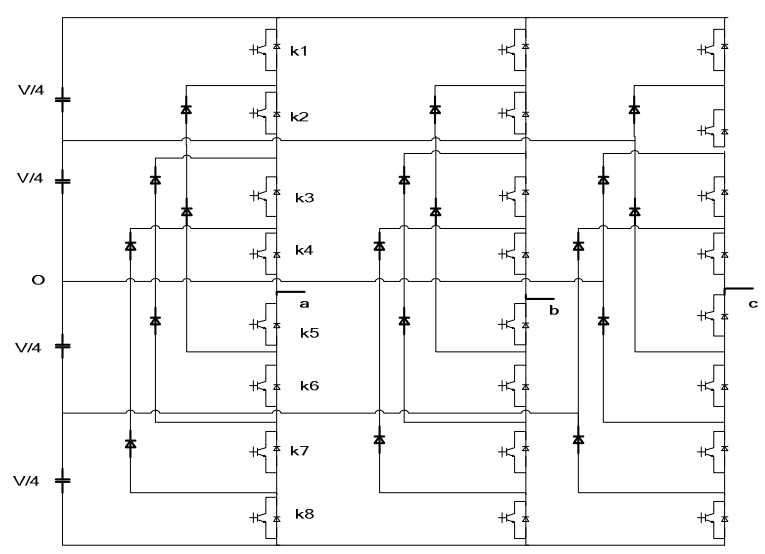

Fig. 1 - Diagram of a NPC converter

The five possible switching sequences of five levels NPC are resumed in the Table I.

TABLE I: States of switches and voltage of the five levels NPC converter

\begin{tabular}{|c|c|c|c|c|c|c|c|c|}
\hline $\mathrm{K}_{1}$ & $\mathrm{~K}_{2}$ & $\mathrm{~K}_{3}$ & $\mathrm{~K}_{4}$ & $\mathrm{~K}_{5}$ & $\mathrm{~K}_{6}$ & $\mathrm{~K}_{7}$ & $\mathrm{~K}_{8}$ & $\mathrm{~V}_{\mathrm{a} 0}$ \\
\hline 1 & 1 & 1 & 1 & 0 & 0 & 0 & 0 & $\mathrm{~V} / 2$ \\
\hline 0 & 1 & 1 & 1 & 1 & 0 & 0 & 0 & $\mathrm{~V} / 4$ \\
\hline 0 & 0 & 1 & 1 & 1 & 1 & 0 & 0 & 0 \\
\hline 0 & 0 & 0 & 1 & 1 & 1 & 1 & 0 & $-\mathrm{V} / 4$ \\
\hline 0 & 0 & 0 & 0 & 1 & 1 & 1 & 1 & $-\mathrm{V} / 2$ \\
\hline
\end{tabular}
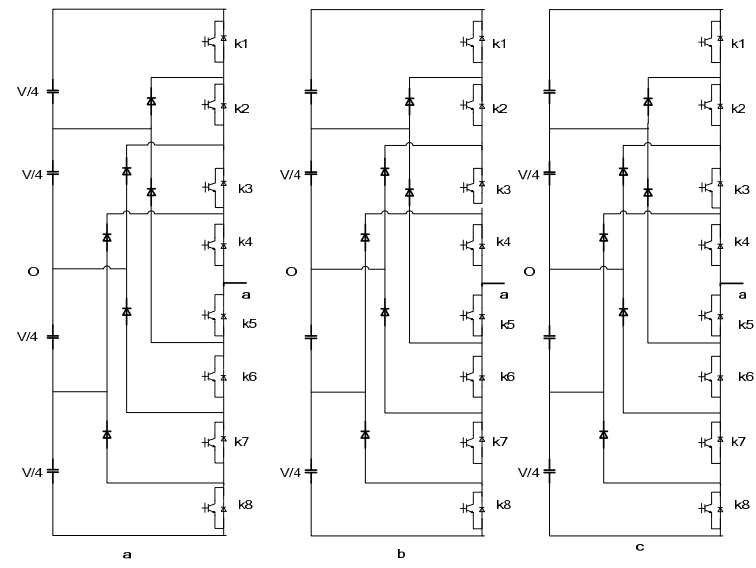

Fig. 2 - Switching principle of 5 levels NPC converter for: a) sequence $1, b)$ sequence $3, \mathrm{c}$ ) sequence 4

\section{B. H-bridge Cascaded Converter}

The topology of multilevel converters based on serial single phase converters (H-bridge or imbricated cells) is shown on Figure 3.

The operating principle of the cascaded H-bridge converter with five levels of voltage is illustrated by a single phase structure. A leg of the cascaded H-bridge converter with five levels is the combination of two classical single phase full bridge converters. The output voltage of the converter is the sum of output voltages of the two bridge converters.

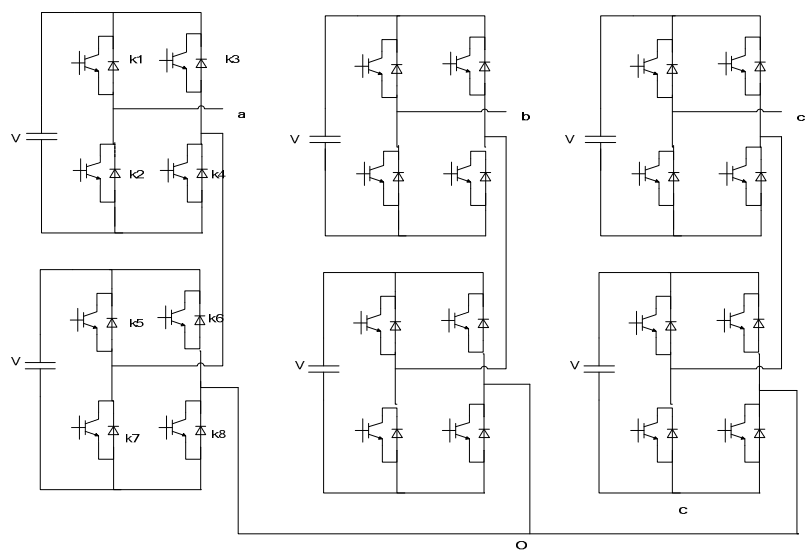

Fig. 3 - Diagram of a cascaded H converter

For the cascaded H-bridge converter with five levels of voltage, there are five sequences:

- Sequence 1:

$\mathrm{K}_{1}, \mathrm{~K}_{4}, \mathrm{~K}_{5}$, and $\mathrm{K}_{8}$ are on and $\mathrm{K}_{2}, \mathrm{~K}_{3}, \mathrm{~K}_{6}$, and $\mathrm{K}_{7}$ are off.

In this case, the first single phase bridge (the top one) give an output voltage $\mathrm{V}$ and the second single phase bridge (the bottom one) give also $\mathrm{V}$ as output voltage. So, the output voltage of the $\mathrm{H}$-bridge cascaded converter with five levels is: $\mathrm{V}_{\mathrm{ao}}=\mathrm{V}+\mathrm{V}=2 \mathrm{~V}$

- Sequence 2: (Figure 4-a)

$\mathrm{K}_{1}, \mathrm{~K}_{4} \mathrm{~K}_{5}$ and $\mathrm{K}_{6}$ are on and $\mathrm{K}_{2}, \mathrm{~K}_{3}, \mathrm{~K}_{7}$ and $\mathrm{K}_{8}$ are off. 
The output voltage of the first bridge is $\mathrm{V}$, however the output voltage of the second bridge is zero. So, the total output voltage is $\mathrm{V}_{\mathrm{ao}}=\mathrm{V}$

- Sequence 3: (Figure 4-b)

$\mathrm{K}_{1}, \mathrm{~K}_{3} \mathrm{~K}_{5}$ and $\mathrm{K}_{6}$ are on and $\mathrm{K}_{2}, \mathrm{~K}_{4}, \mathrm{~K}_{7}$ and $\mathrm{K}_{8}$, are off. The output voltage of the two single cascaded bridges is zero: $\mathrm{V}_{\mathrm{ao}}=0$

- Sequence 4:

$\mathrm{K}_{2}, \mathrm{~K}_{3}, \mathrm{~K}_{7}$ and $\mathrm{K}_{8}$ are on and $\mathrm{K}_{1}, \mathrm{~K}_{4}, \mathrm{~K}_{5}$ and $\mathrm{K}_{7}$ are off. In this case, the output voltage is: $\mathrm{V}_{\mathrm{ao}}=-\mathrm{V}$

- Sequence 5: (Figure 4-c)

$\mathrm{K}_{2}, \mathrm{~K}_{3}, \mathrm{~K}_{6}$ and $\mathrm{K}_{7}$ are on and $\mathrm{K}_{1}, \mathrm{~K}_{4}, \mathrm{~K}_{5}$ and $\mathrm{K}_{8}$, are off. The output voltage is: $\mathrm{V}_{\mathrm{ao}}=-\mathrm{V}-\mathrm{V}=-2 \mathrm{~V}$

The value of reverse voltage off the switches during the operating sequence is $\mathrm{V}_{\mathrm{ki}}=\mathrm{V} \quad \mathrm{i}=1 \ldots .8$

The five possible switching sequences are resumed in the Table II.

Table II : States of switches and voltage of $\mathrm{H}$ type converter

\begin{tabular}{|c|c|c|c|c|c|c|c|c|}
\hline $\mathrm{K}_{1}$ & $\mathrm{~K}_{2}$ & $\mathrm{~K}_{3}$ & $\mathrm{~K}_{4}$ & $\mathrm{~K}_{5}$ & $\mathrm{~K}_{6}$ & $\mathrm{~K}_{7}$ & $\mathrm{~K}_{8}$ & $\mathrm{~V}_{\mathrm{a} 0}$ \\
\hline 1 & 0 & 0 & 1 & 1 & 0 & 0 & 1 & $2 \mathrm{~V}$ \\
\hline 1 & 0 & 0 & 1 & 0 & 1 & 0 & 1 & $\mathrm{~V}$ \\
\hline 0 & 1 & 0 & 1 & 0 & 1 & 0 & 1 & 0 \\
\hline 0 & 1 & 1 & 0 & 0 & 1 & 0 & 1 & $-\mathrm{V}$ \\
\hline 0 & 1 & 1 & 0 & 0 & 1 & 1 & 0 & $-2 \mathrm{~V}$ \\
\hline
\end{tabular}
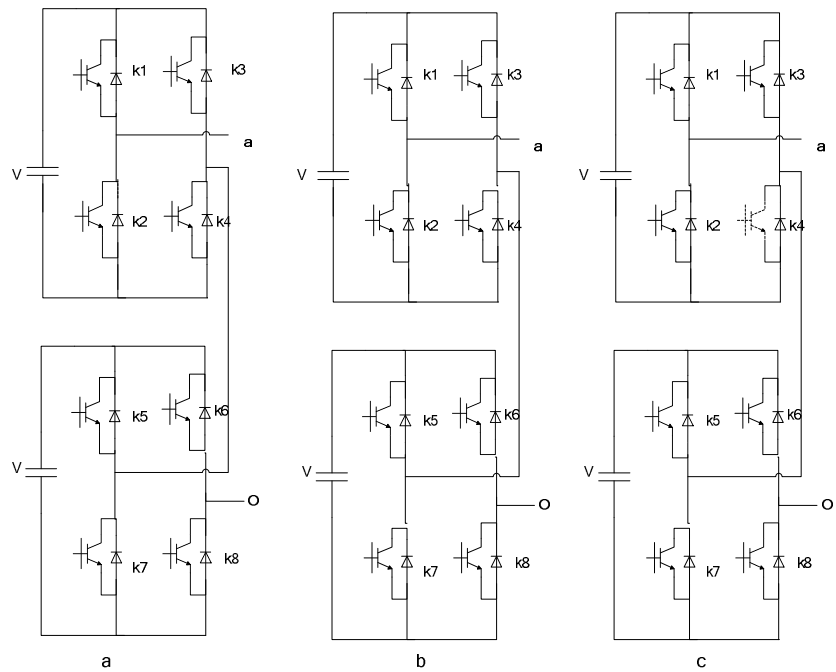

Fig. 4- NPC 5 levels: Principle and examples of switching mechanism a) sequence2, b) sequence 3 , c) sequence 5 .

\section{Generalization}

\section{A. Multilevel Voltage NPC Converter}

The study of any multilevel NPC converters is derived from the analysis of three level and five level NPC converters. Figure 5 shows the configuration of a leg of the multilevel NPC converter.
For a multilevel NPC converter, the number of capacitors $\mathrm{C}$, switches $\mathrm{K}$ (per phase) and parallel diodes $\mathrm{D}$ are ruled by the following relations:

$$
C=N-1, \quad K=2(N-1), \quad D=2(N-2)
$$

$\mathrm{N}-1$ switches are implemented per phase, and $\mathrm{N}$ operating conditions allow the generation of $\mathrm{N}$ voltage levels.

The first sequence will correspond to the state where all switches $\mathrm{K}_{1}$ to $\mathrm{K}_{\mathrm{N}}$ will be closed and the others $\mathrm{K}_{\mathrm{N}}$ à $\mathrm{K}_{2(\mathrm{~N}-1)}$ opened. In this case $\mathrm{V}_{\mathrm{ao}}=+\frac{\mathrm{V}}{2}$.

The $\mathrm{m}^{\text {th }}$ operating sequence corresponds to the state where switches $K_{m}$ to $K_{N+m-2}$ are closed and the others switches opened.

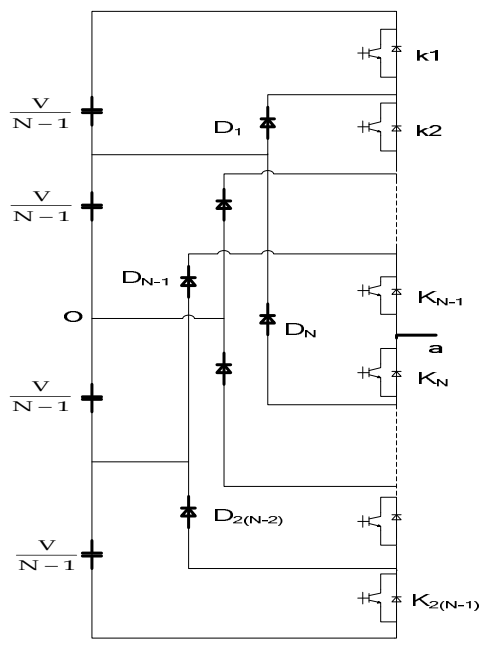

Fig. 5- A leg of multilevel converter

\section{B Multilevel cascaded H-bridge converter}

The three phased multilevel voltage $\mathrm{H}$-bridge cascaded is shown in Figure 6. Each phase of the converter has $(N-1) / 2$ classical single bridge level. These bridges are cascaded so that the output voltage of the cascaded bridge is the sum of the output voltage of each single bridge. For each phase, $2(N-1)$ controlled switches and $(N-1) / 2$ DC sources are used. In each classical single phase bridge, there are two complementary controlled switches. The choice of switch to be closed or to be opened depends on the expected output voltage. To obtain voltage level $\mathrm{V}$, switches $\mathrm{K}_{1}$ and $\mathrm{K}_{4}$ must be closed and $\mathrm{K}_{2}$ and $\mathrm{K}_{4}$ must be opened. That will set the output voltage of the $\mathrm{H}$ cascaded converter to $\mathrm{V}_{\mathrm{ao}}=\frac{\mathrm{N}-1}{2} \mathrm{~V}$. To get voltage level $-\mathrm{V}, \mathrm{K}_{1}$ and $\mathrm{K}_{4}$ are opened and $\mathrm{K}_{2}$ and $\mathrm{K}_{4}$ are closed. The zero voltage level is obtained by closing the two bordering switches of each leg; the others two switches remain opened.

The multilevel H-bridge cascaded converters are obtained by combining different states of switches. The first voltage level 
corresponds to $\mathrm{V}_{\mathrm{ao}}=\frac{\mathrm{N}-1}{2} \mathrm{~V}$ and the last level is $\mathrm{V}_{\mathrm{ao}}=-\frac{\mathrm{N}-1}{2} \mathrm{~V}$.
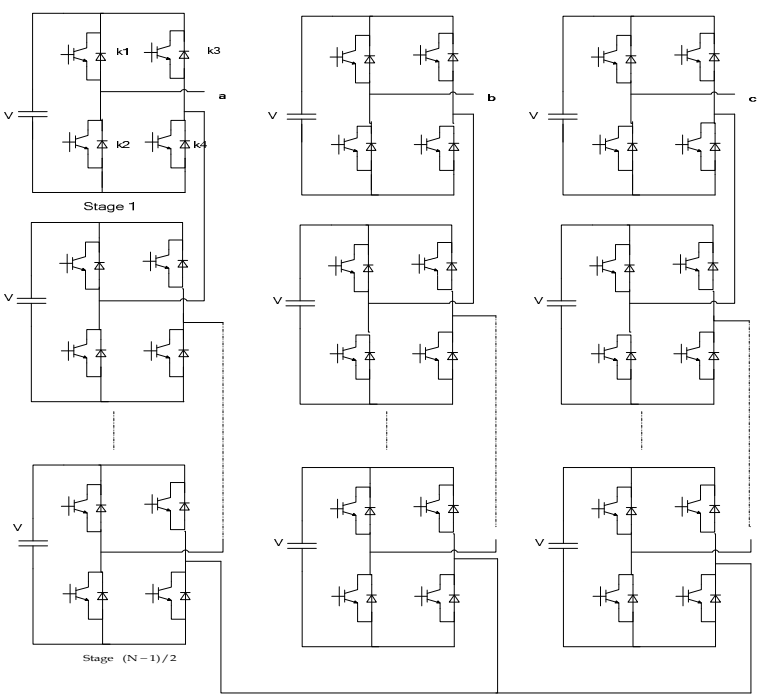

Fig. 6- Generalized scheme of H-bridge cascaded converter

\section{Principle of Control}

Many methods to generate pulse width modulation (PMW) signals for multilevel converter have been reported during the last two decades. There are two pulse width modulation technologies: the interceptive modulation and the space vector modulation (SVPWM) [5]. Recently, with the development digital technology, the SVPWM (Space Vector Pulse Width Modulation) is widely used, not only because of its easily implementation, but also for the quality of signals obtained by this method, in particular low displacement current factor [5] [6]. The major inconvenience of this method is that, the control algorithm to generate control signals are becoming increasingly complex for converters with voltage levels more than three [5].

To generate PWM control for a multilevel converter, N-1 triangular carriers are necessary and these carriers have the same frequency $f_{c}$ and the same amplitude $A_{c}$. Carriers can be horizontally or vertically shifted. If horizontally then the phase shift between two consecutives signals is given by $\frac{2}{N-1}$. If vertically, triangular signals can be in phase or not and take up a continue band with the same vertical phase shift. The carriers are then compared with the reference signal with amplitude $A_{r}$ and frequency $f_{r}$. Each comparison gives 1 if a carrier higher or equal to the reference, and zero in the opposite case. At the output of the modulator, the sum of comparison results is then decoded, and gave the corresponding value for each voltage level [2], [5].
For a multilevel converter, the index of modulation in amplitude $\mathrm{m}_{\mathrm{a}}$ and the index of modulation in frequency $\mathrm{m}_{\mathrm{f}}$ are defined as:

$$
m_{a}=\frac{A r}{(N-1) A_{c}}, \quad m_{f}=\frac{f c}{f r}
$$

For simulation, the chosen PMW method is the phase shifted (PS). In the PS method, all the carriers have the same amplitude and the same frequency, but their phases are mutually shifted by 90 degrees. This method presents a better total harmonic distortion (THD) for all values of modulation index [6]. Figure 7 shows layout of triangular carrier and reference sinus signal for the phase shifted PWM method.

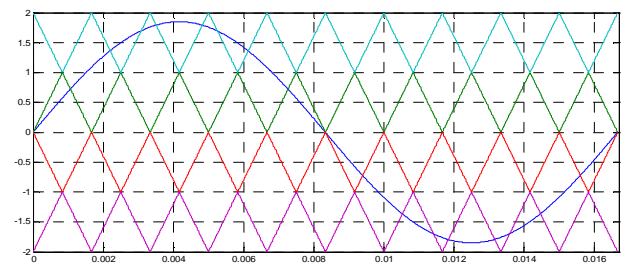

Fig. 7- Control signal of the phase shifted method for 5 Levels

\section{Simulation}

Simulation study was carried out for two three phase topologies: the three levels and the five levels converters. The phase shifted (PS) PWM control method was used for power switches. The input voltage source is $110 \mathrm{~V}$, the load is a of a resistance $R=1 \Omega$ in series with an inductance $L=0.75 H$. The power factor is $\cos \varphi=0.80$.

\section{A. Three Phase NPC Converter}

Figure 8 shows voltage signals between phase a and neutral $n\left(v_{a n}\right)$, currents of line $\left(I_{a}, I_{b}\right.$ et $\left.I_{c}\right)$ and voltage between phase $\mathrm{a}$ and phase $\mathrm{b}\left(\mathrm{v}_{\mathrm{ab}}\right)$ obtained at the output of the three phase five level NPC converter. Figures 9 and 10 show respectively the harmonic spectrum of the voltage $\mathrm{v}_{\mathrm{ab}}$ and the current $I_{a}$.
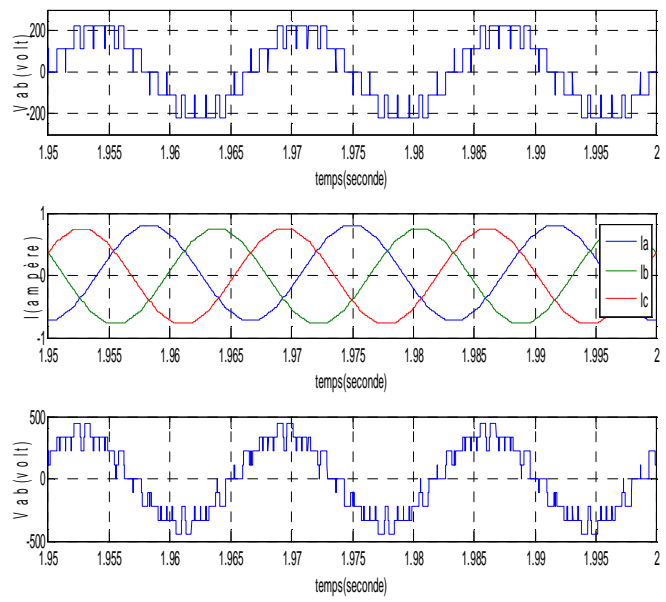

Fig. 8: Waveforms of the five levels NPC converter 


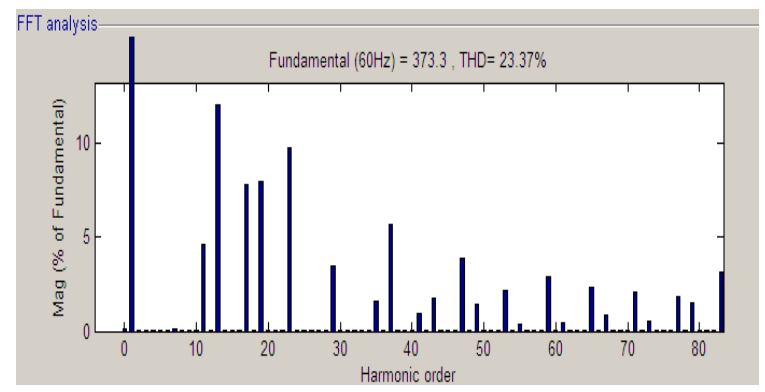

Fig. 9: Harmonic spectrum of the voltage $v_{a b}$

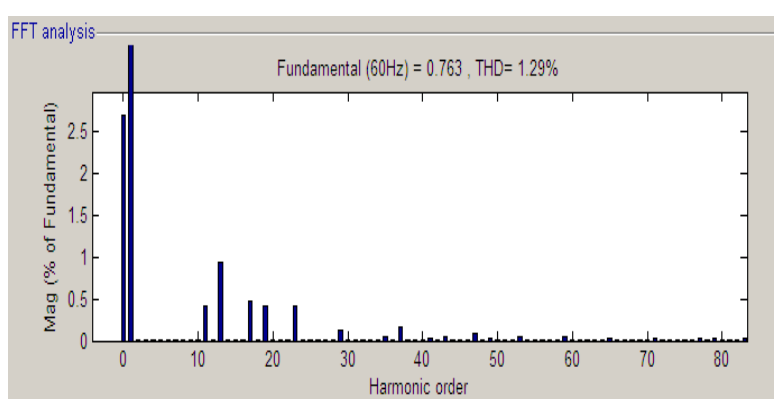

FIG. 10: Harmonic spectrum of the current $I_{a}$

\section{B. Three Phase H-bridge Cascaded Converter}

Figure 11 shows voltage between phase a and neutral $n$ $\left(\mathrm{v}_{\mathrm{an}}\right)$, the voltage between phase $\mathrm{a}$ and phase $\mathrm{b}\left(\mathrm{v}_{\mathrm{ab}}\right)$ and currents of lines $\left(\mathrm{I}_{\mathrm{a}}, \mathrm{I}_{\mathrm{b}}\right.$ and $\left.\mathrm{I}_{\mathrm{c}}\right)$ obtained at the output of the three phase five levels NPC. Figures 12 and 13 shows respectively harmonic spectrum of voltage $v_{a b}$ and current $I_{a}$
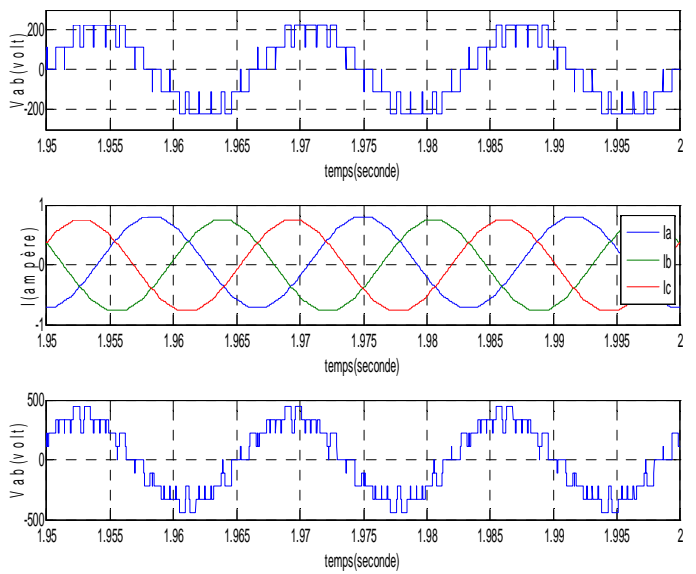

Fig. 11 : Waveforms of the cascaded converter

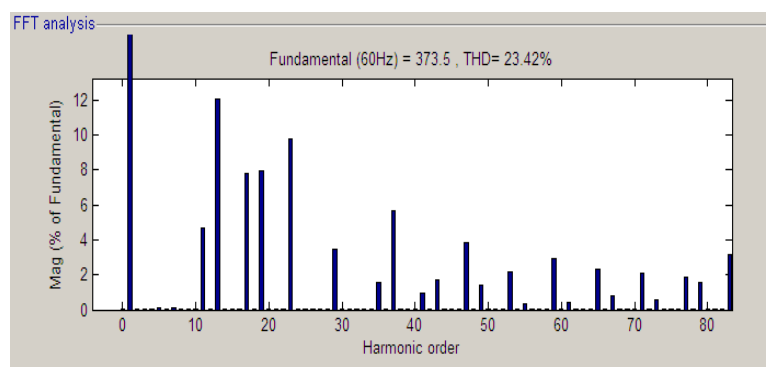

Fig. 12: Harmonic spectrum of the voltage $v_{a b}$

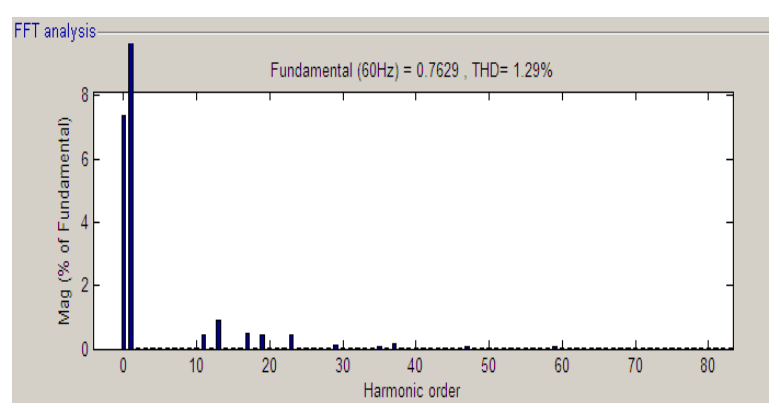

Fig.13: Harmonic spectrum of the load current

Table III shows total harmonic distortion of voltage and current of the two topologies of five levels converters topologies as function of the carrier and frequency. The two converters produce almost identical output characteristics. Moreover, the higher is the frequency of the carrier, the better (lower THD) are the obtained signals.

TABLE III: Simulation results of the two converters topologies

\begin{tabular}{|l|c|c|c|c|}
\hline $\begin{array}{l}\text { Carrier } \\
\text { frequency } \\
(\mathrm{Hz})\end{array}$ & Topology & $\begin{array}{c}\text { Fondamental } \\
\text { voltage } \mathrm{v}_{\mathrm{ab}}(\mathrm{V})\end{array}$ & $\begin{array}{c}\text { Voltage } \\
\text { THD_vab }\end{array}$ & $\begin{array}{c}\text { Current } \\
\text { THD_I (\%) }\end{array}$ \\
\hline \multirow{3}{*}{1080} & NPC & 373.3 & 23.37 & 1.29 \\
\cline { 2 - 5 } & $\mathrm{H}$ & 373.5 & 23.42 & 1.29 \\
\hline \multirow{3}{*}{3000} & $\mathrm{NPC}$ & 373.3 & 26.23 & 0.45 \\
\cline { 2 - 5 } & $\mathrm{H}$ & 373.4 & 26.32 & 0.45 \\
\hline \multirow{2}{*}{6000} & $\mathrm{NPC}$ & 373 & 26.24 & 0.23 \\
\cline { 2 - 5 } & $\mathrm{H}$ & 373.1 & 26.34 & 0.23 \\
\hline \multirow{2}{*}{9600} & $\mathrm{NPC}$ & 373.7 & 26.06 & 0.19 \\
\cline { 2 - 5 } & $\mathrm{H}$ & 373.8 & 26.16 & 0.20 \\
\hline
\end{tabular}

\section{Conclusion}

The analysis of two different topologies of multilevel converters shows that multilevel converters have much more advantages over traditional two level converters. It also comes out that the converters with cascaded cells appear to be more advantageous multilevel solution especially when the number of levels becomes more important. However, it requires the isolation of the power source of each H-bridge, which compromises its advantage over the NPC converter. Indeed, for three phase applications and for a small number of levels, NPC converters are interesting, because capacitors are shared by different legs. This allows balancing of the power circulating between phases and reduces significantly the size of intermediate capacitors. Five level converters give cleaner waveforms than three level converters. However, the difference is small because the three level converters have signals with quite good quality. Moreover, they use less power devices and their control is easier. Also the phase to neutral voltage of the five levels converter is identical to the one in the three levels converter. 


\section{References}

[1] Ying Cheng, Chang Qian, Mariesa L. Crow, Steve Pekarek, "A Comparison of Diode-Clamped and Cascaded Multilevel Converters for a STATCOM With Energy Storage" Industrial Electronics, IEEE Transactions on Volume 53, Issue 5, Oct. 2006 Page(s): 1512 - 1521.

[2] Joseph Song Manguelle, Convertisseurs multiniveaux asymétriques alimentés par transformateurs multi-secondaires basse-fréquence : réactions au réseau d'alimentation, Thèse $\mathrm{n}^{\circ}$ 3033 (2004), École Polytechnique Fédérale de Lausanne, Suisse.

[3] Jean-Sébastien Mariéthoz, Étude formelle pour la synthèse de convertisseurs multiniveaux asymétriques: topologies, modulation et commande, thèse $\mathrm{n}^{\circ} 3188$ (2005), École Polytechnique Fédérale de Lausanne, Suisse.

[4] Yakouba Khadija, Réduction des effets de la tension homopolaire dans les associations onduleurs multiniveaux moteur à induction, Mémoire de Magister, 2005, Université de Batna, Algérie.

[5] Wu Hongyang, He Xiangning; "Power Electronics and Motion Control Conference, 2000. Proceedings", IPEMC 2000. The Third International Volume 3, 15-18 Aug. 2000 Page(s): 1099 1103.

[6] A. Radan, A.H.Shahirinia "Novel Carrier-Based PWM Methods for Multi-level Inverters", EPE Journal, ISSN 0939-8368 Vol.18-N²- April, May, June 2008 pages 16-21. 